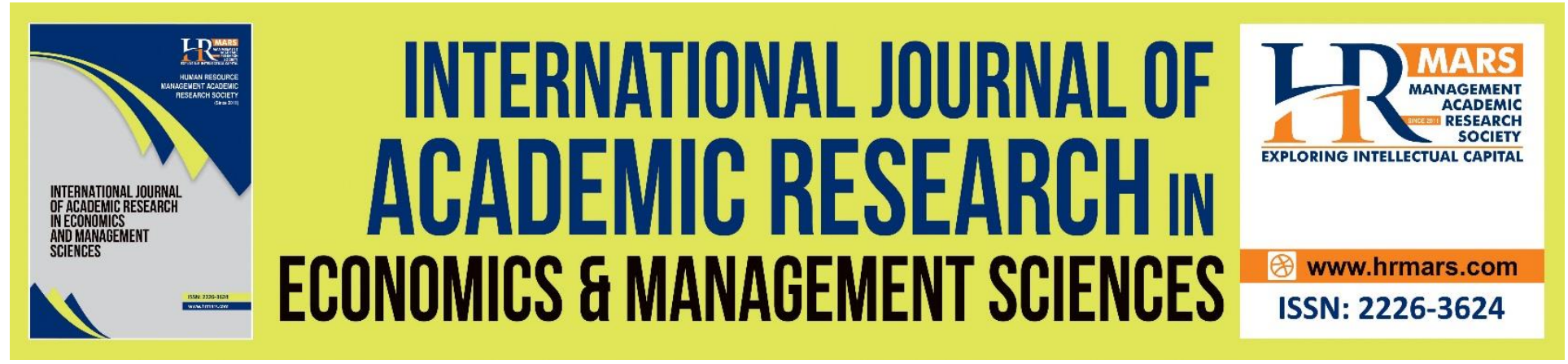

\title{
The TOPSIS of Different Ideal Solution and Distance Formula of Fuzzy Soft Set in Multi-Criteria Decision Making
}

Erin Nabilah Rejab, Nur Ashikin Haridan, Nur Emmy Najihah Shahril Nizam, Zahari Md Rodzi

To Link this Article: http://dx.doi.org/10.6007/IJAREMS/v10-i2/10063

DOI:10.6007/IJAREMS/v10-i2/10063

Received: 01 April 2021, Revised: 30 April 2021, Accepted: 25 May 2021

Published Online: 26 June 2021

In-Text Citation: (Rejab et al., 2021)

To Cite this Article: Rejab, E. N., Haridan, N. A., Nizam, N. E. N. S., \& Rodzi, Z. M. (2021). The TOPSIS of Different Ideal Solution and Distance Formula of Fuzzy Soft Set in Multi-Criteria Decision Making. International Journal of Academic Research in Economics and Managment and Sciences, 10(2), 87-91.

Copyright: (C) 2021 The Author(s)

Published by Human Resource Management Academic Research Society (www.hrmars.com)

This article is published under the Creative Commons Attribution (CC BY 4.0) license. Anyone may reproduce, distribute, translate and create derivative works of this article (for both commercial and non-commercial purposes), subject to full attribution to the original publication and authors. The full terms of this license may be seen at: http://creativecommons.org/licences/by/4.0/legalcode

Vol. 10, No. 2, 2021, Pg. 87 - 91

http://hrmars.com/index.php/pages/detail/IJAREMS

JOURNAL HOMEPAGE

Full Terms \& Conditions of access and use can be found at http://hrmars.com/index.php/pages/detail/publication-ethics 


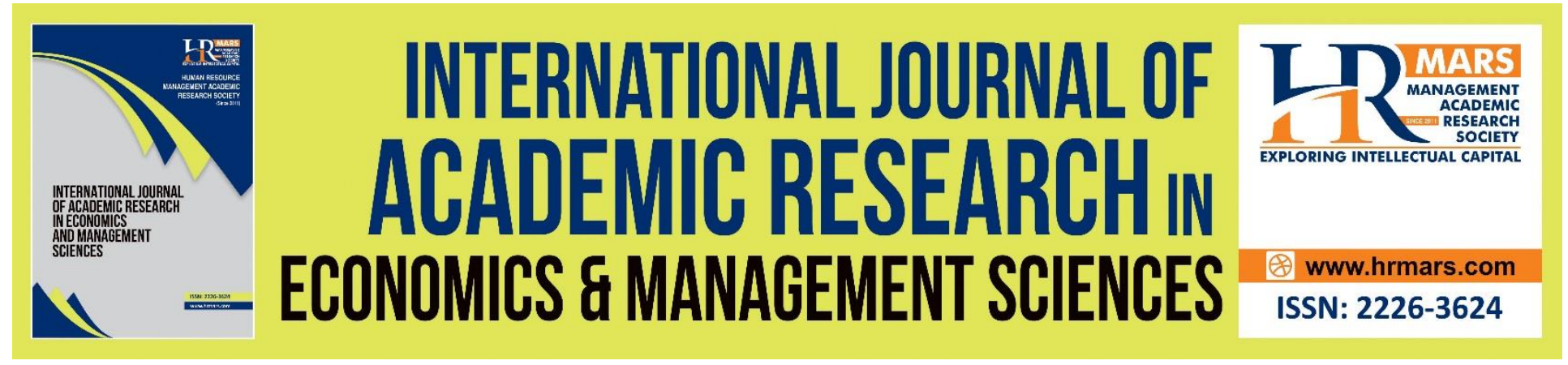

\title{
The TOPSIS of Different Ideal Solution and Distance Formula of Fuzzy Soft Set in Multi-Criteria Decision Making
}

\author{
Erin Nabilah Rejab, Nur Ashikin Haridan, Nur Emmy Najihah \\ Shahril Nizam, Zahari Md Rodzi
}

Faculty of Computer and Mathematical Sciences, Universiti Teknologi MARA Cawangan Negeri

Sembilan, Kampus Seremban, Malaysia

Email: zahari@uitm.edu.my

\begin{abstract}
Molodtsov pioneered the concept of fuzzy soft set, which was a hybrid of fuzzy set and soft set. The fuzzy soft set is used in the Technique for Order Preference by Similarity to Ideal Solution (TOPSIS) method to deal with imprecision in order to obtain the best compromise solution, which is the solution that is closest to the ideal solution, and the theory is demonstrated using multiobserver performance evaluation. Two distinct FPIS and FNIS values were used in this study: maximum and minimum values, as well as universal set values $(1,1,1) \cdot(0,0,0)$. Additionally, this study utilised three distinct distance formulas: separation distance, Euclidean distance, and Chu's distance. Two numerical examples of multi- criteria decision making (MCDM) problems were used in this study to demonstrate the methods' consistency. Thus, it is demonstrated that our proposed methods are consistent with the ranking given by both examples.

Keywords: Fuzzy Soft Set, Fuzzy Ideal Solution, Distance, Multi-criteria Decision Making, TOPSIS.
\end{abstract}

\section{Introduction}

Molodtsov (1999) pioneered the use of soft set theory as a mathematical tool for resolving ambiguities that traditional mathematical theory is incapable of resolving. The soft set theory has been applied to a wide variety of fields, including engineering, economics, and social sciences, to aid in problem solving (Molodtsov, 1999). A detailed theoretical study was conducted and presented on the application of soft set theory to decision-making problems involving the reduction of rough sets (Maji, Biswas, \& Roy, 2003). They were also the first to introduce the concept of fuzzy soft set in 2001, combining fuzzy set and soft set theory. Roy and Maji (2007) present a method for object recognition from inaccurate multi-observer data in their article "A fuzzy soft set theoretic approach to decision making problems." The method entails creating a comparison table for decision making from a fuzzy soft set in a parametric sense (Roy \& Maji, 2007). The final decision is made based on the comparison table's maximum score. Majumdar 
and Samanta (2010) defined generalised fuzzy soft sets and their properties in their article "Generalised fuzzy soft sets." Additionally, they demonstrated how fuzzy soft sets can be used to solve decision-making and medical diagnosis problems. The authors discussed the similarity of two generalised fuzzy soft sets in the context of medical diagnosis. To summarise, modified fuzzy soft sets will be more effective at resolving a variety of uncertainty problems and will produce more natural results (Majumdar \& Samanta, 2010). The are many other study of fuzzy soft and their extensions in MCDM (Alcantud et al., 2016; Alsager et al., 2018; Bashir \& Salleh, 2012; Beg \& Rashid, 2016; Khan et al., 2019; Li et al., 2019; Mokhtia et al., 2020; Sun et al., 2018; Wang, et al., 2015; Wang \& Qin, 2019).

TOPSIS is a practical method for dealing with MCDM in the real world. Hwang and Yoon first introduced TOPSIS in 1981. It aids decision makers in organising the problem at hand and conducting analyses, comparisons, and rankings of alternative solutions. The TOPSIS approach's objective is for the most preferred alternative to be the closest to the positive ideal solution and the furthest from the negative ideal solution. The purpose of this study was to introduce the TOPSIS method for decision making based on different ideal solution and distance formula of fuzzy soft. The researcher proposed a new decision-making model in which the outcomes of various examples led to similar conclusions. Thus, the new model is relevant for aggregation, is relatively simple to implement, and will not impose a greater computational burden than the TOPSIS method.

This paper is structured as follows. The following sections Section 2 presents the fundamental definitions of soft sets, fuzzy soft sets, fuzzy TOPSIS, the ideal solution in fuzzy TOPSIS, and the fuzzy soft set distance formula in TOPSIS. Section 3 discusses fuzzy soft sets in TOPSIS that have a variety of ideal solutions and distance formulas. This section provides an overview of the integrated fuzzy TOPSIS method's flowchart and details the steps involved in creating a fuzzy soft set in TOPSIS. Section 4 discusses two numerical examples involving the use of a fuzzy soft set in TOPSIS with varying ideal solution values and also varying distance formulas. Finally, section 5 brings the paper to a close.

\section{Preliminaries}

In this section, we briefly review basic theoretical background on soft sets, fuzzy soft sets, fuzzy TOPSIS, the ideal solution in fuzzy TOPSIS, and distance formula of fuzzy soft set in TOPSIS.

\section{Definition of Soft Set}

Molodtzov (1999) first introduced soft set as a mathematical method to solve problems involving uncertainties. Soft set is an alternative to solve the problems associated with data loss, incomplete data and ambiguous data. Soft set consist of universal set, parameters and function. Let $U$ be the universe set and $K$ be the set of parameters or attributes with respect to $U$. Then soft set is defined as follows;

A pair $(\mathrm{F}, \mathrm{R})$ is called soft set over $U$, where $R \subseteq K$ and $\mathrm{F}$ is a mapping given by $F: R \rightarrow P(U)$. In other words, a soft set over $U$ is a parameterized family of subsets of $U$. $R$ is the parameter set of the soft set $(\mathrm{F}, \mathrm{R})$ and for $e \in R, F(e)$ may be considered as the set of e-elements or e-approximate elements of soft sets $(F, R)$. Thus, $(F, R)$ is defined as:

$$
(F, R)=\{F(e) \in P(U): e \in K, F(e)=\varnothing \text { if } \mathrm{e} \notin \mathrm{R}
$$




\section{Definition of Fuzzy Soft Set}

Maji, Biswas and Roy (2001) presented the concept of fuzzy soft sets. Fuzzy soft sets are defined as follows; A pair $(\mathrm{F}, \mathrm{R})$ is a fuzzy soft set over $U$ where $F: R \rightarrow \tilde{P}(U)$ is mapping from $\mathrm{R}$ into $\tilde{P}(U)$ where when $\tilde{P}(U)$ denotes the set of all fuzzy sets on $U$ and $R \subseteq E$. In other words, let $x \in U$ and $e \in R$. F (e) is a fuzzy subset of $U$ and it is called crisp subset of $U$, then $(F, R)$ is degenerated to be the standard soft set (Maji et al. 2001). Let $F(e)(x)$ denote the degrees of membership that objects $x$ holds parameter $e$, and then $F(e)$ can be written as a fuzzy set such that:

$$
F(e)=\{x / F(e)(x) \mid x \in U\}
$$

For instance, if we take example soft set above, with

$$
\begin{aligned}
& F\left(e_{1}\right)=\left\{f_{1} / 0.8, f_{2} / 0.2, f_{3} / 0.1, f_{4} / 0.3\right\}, \\
& F\left(e_{2}\right)=\left\{f_{1} / 0.9, f_{2} / 0.5, f_{3} / 0.8, f_{4} / 0.2\right\}, \\
& F\left(e_{3}\right)=\left\{f_{1} / 0.5, f_{2} / 0.1, f_{3} / 0.6, f_{4} / 0.7\right\}
\end{aligned}
$$

then,

$$
(F, R)=\left\{F\left(e_{1}\right)=\left\{f_{1} / 0.8, f_{2} / 0.2, f_{3} / 0.1, f_{4} / 0.3\right\}, F\left(e_{2}\right)=\left\{f_{1} / 0.9, f_{2} / 0.5, f_{3} / 0.8, f_{4} / 0.2\right\}\right\}
$$

\section{Definition of Fuzzy TOPSIS}

In this study, the mathematical concept of Fuzzy TOPSIS is shown as below:

Step 1: Build the fuzzy decision matrix, FDM.

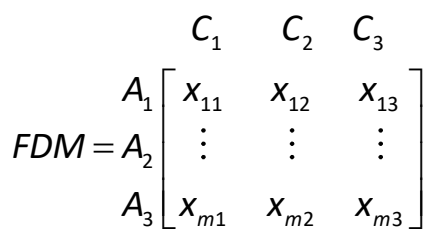

And criteria are composed by the following equation:

$$
\tilde{W}=\left(\tilde{W}_{1}, \tilde{W}_{2}, \cdots, \tilde{W}_{m}\right)
$$

Step 2: Normalized the fuzzy decision matrix (NFDM) by using relative performance of the generated design alternatives.

$$
N F D M=R_{i j}=\frac{X_{i j}}{\sqrt{\sum_{i=1}^{m} X_{i j}^{2}}}
$$

Step 3: Determine the weighted normalized fuzzy decision matrix.

$$
V=V_{i j}=W_{j} \times R_{i j}
$$

Where $j=1,2 \ldots, m$ and $i=1,2, \ldots, n$ 
Step 4: Identify the Fuzzy Positive Ideal Solution (FPIS, $A^{+}$) and Negative Ideal Solution (FNIS, $A^{-}$).

Step 5: Calculate the distance of each alternative from the ideal and non-ideal solution.

Step 6: Measure the closeness coefficient of each alternative to the ideal solution.

For each competitive alternative the closeness coefficient of the potential location with respect to the ideal solution is computed.

$$
C_{i}=\frac{S_{i}^{-}}{S_{i}^{+}+S_{i}^{-}} \quad 0 \leq C_{i} \leq 1
$$

Step 7: Rank preference order

The rank of alternatives will be obtained according to the closeness coefficient in descending order which allow relatively better performances to be compared. According to the value $C_{i}$, the higher the value of closeness coefficient, the higher the ranking order and hence the better the performance of the alternatives.

\section{Ideal Solution in Fuzzy TOPSIS}

There are two values of fuzzy positive ideal solution (FPIS) and fuzzy negative ideal solution (FNIS) that have been used. One of the universal set of FPIS and FNIS values are $(1,1,1)$ and $(0,0,0)$ and the other values are maximum value and minimum value. Both of these FPIS and FNIS values are frequently used by many researchers but in this study, we would like to compare both values and determined which one is more suitable.

A value FPIS and FNIS that have been used are $(1,1,1)$ and $(0,0,0)$ based on the weighted normalized fuzzy decision matrix that the range fit to the closed interval $[0,1]$. The FPIS, $\mathrm{A}^{+}$and FNIS, $A^{-}$were decided as defined in the following equations (Alidoosti, Yazdani, Fouladgar, \& Basiri, 2012). For benefit criterion, FPIS and FNIS are classified as:

$$
A^{+}=(1,1,1, \ldots, 1) \text { and } A^{-}=(0,0,0, \ldots 0)
$$

While for cost criterion, FPIS and FNIS are classified as:

$$
A^{+}=(0,0,0, \ldots 0) \text { and } A^{-}=(1,1,1, \ldots, 1)
$$

The other FPIS and FNIS is presented by Hwang and Yoon (1981) for solving MCDM problem. The concept of FPIS refer to the chosen alternative that have the shortest distance from the positive ideal solution and FNIS refer to the chosen alternative that have the longest distance from the negative ideal solution. For example, FPIS maximize the benefit criteria and minimize the cost criteria whereas the FNIS maximize the cost criteria and minimize the benefit criteria. The FPIS values is determined by the maximum value and FNIS values is determined by the minimum value to select the best alternative in solving problems. The maximum and minimum values can be defined as follows:

$$
\begin{aligned}
& A^{+}=\left(v_{1}^{+}, v_{2}{ }^{+}, \ldots, v_{m}{ }^{+}\right)=\left\{\max _{j} v_{i j}|j=1,2, \ldots, m|\right\} \\
& A^{-}=\left(v_{1}^{-}, v_{2}^{-}, \ldots, v_{m}^{-}\right)=\left\{\min _{j} v_{i j}|j=1,2, \ldots, m|\right\}
\end{aligned}
$$




\section{Distance Formulas}

This study used FPIS, FNIS with three different kind of distance formula to compare whether there is a different between the ranks of the closeness coefficient of each alternative. The distance formula that has been used are Separation distance, Euclidean distance and distance formula by Chu (2002). Separation distance is applied by Hwang and Yoon (1981) in the TOPSIS method to obtain the closeness coefficient of each alternative. The distance $\left(S^{+}\right.$and $\left.S^{-}\right)$of each alternative from $A^{+}$and $A^{-}$can be currently calculated by the area compensation method as shown in equation (16) and (17).

$$
\begin{gathered}
S^{+}=\sqrt{\sum_{j=1}^{n}\left(V_{j}^{+}-V_{i j}\right)^{2}} \quad i=1, \ldots, m \\
S^{-}=\sqrt{\sum_{j=1}^{n}\left(V_{j}^{-}-V_{i j}\right)^{2}} \quad . i=1, \ldots, m .
\end{gathered}
$$

Roshandel, Miri-Nargesi, Hatami-Shirkouhi (2013) apply Euclidean distance in the study of the hierarchical fuzzy TOPSIS by formula:

$$
\begin{gathered}
S^{+}=\sqrt{\frac{1}{s} \sum_{i=1}^{n}\left(V_{i j}-V^{+}{ }_{j}\right)^{2}} \quad i=1, \ldots, m \text { and } \mathrm{s}=\text { number of alternatives } \\
S^{-}=\sqrt{\frac{1}{s} \sum_{i=1}^{n}\left(V_{i j}-V^{-}{ }_{j}\right)^{2}} \quad i=1, \ldots, m \text { and } \mathrm{s}=\text { number of alternatives }
\end{gathered}
$$

Chu (2002) applied distance in the study of fuzzy TOPSIS approach by formula:

$$
\begin{gathered}
S^{+}=\sum_{i=1}^{n}\left|V_{i j}-V^{+}{ }_{j}\right| \quad i=1, \ldots, n \\
S^{-}=\sum_{i=1}^{n}\left|V_{i j}-V^{-}{ }_{j}\right| \quad i=1, \ldots, n
\end{gathered}
$$

\section{TOPSIS of Fuzzy Soft Sets with Distinct Ideal Solutions and Distance Formulas}

In this section, we present the flowchart of integrated fuzzy TOPSIS and the steps of fuzzy soft set in TOPSIS to further explained the study.

\subsection{Flowchart of Integrated Fuzzy TOPSIS Method}

The fuzzy TOPSIS method introduced by Hwang and Yoon (1981) was analyze in the fourth step where the values of FPIS and FNIS was changed to the universal values $(1,1,1)$ and $(0,0,0)$ and the fourth step where two other distance methods were applied. The flowchart is illustrated as below: 


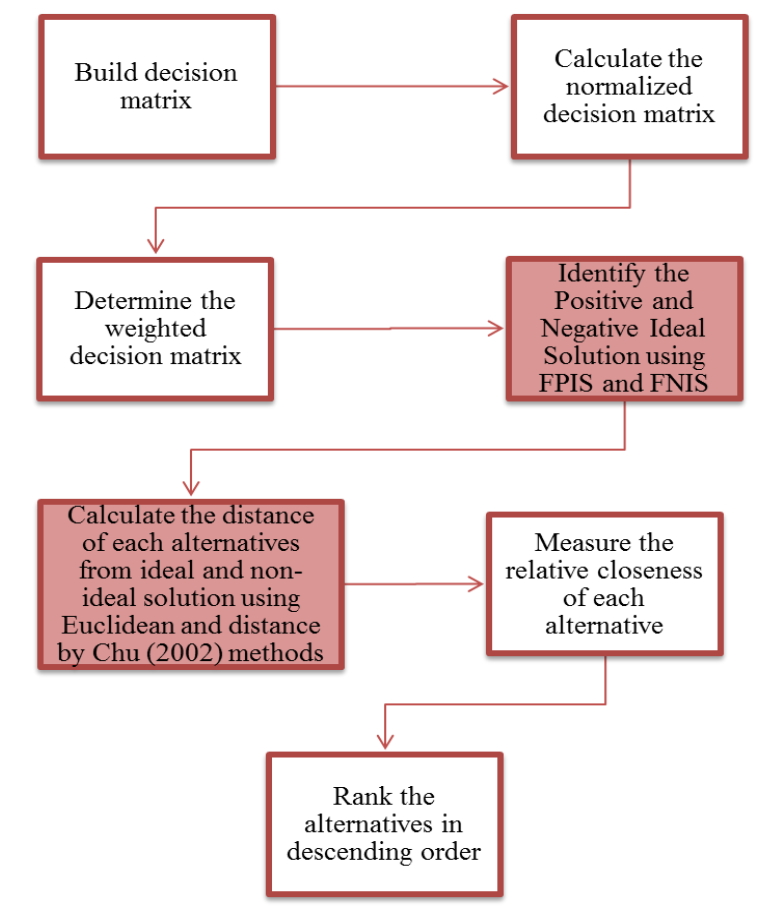

Figure 1: Flowchart of Integrated Fuzzy TOPSIS method

\section{Numerical Examples}

In this section, we will present two numerical examples of applications that we will incorporate into our methodologies in order to demonstrate the practicality of our suggested method.

The first application that we obtained is from an article by Eraslan (2015) assume that a real estate agent has a set of different types of houses which may be characterized by a set of all parameter. For the parameters stand for "cheap", "modern", "large" respectively. Then we can give the following examples, suppose that three decision makers come to the real estate agent to buy a house. Firstly, each decision maker has to consider their own set of parameters. Then, they can construct their fuzzy soft sets. Next, we select a house on the basis for the sets of decision makers' parameters. Assume that decision makers and construct fuzzy soft sets, respectively as follows:

$$
\begin{array}{lll}
D_{1}\left(x_{1}\right)=\left\{0.5 / u_{1}, 0.2 / u_{2}, 0.5 / u_{3}\right\} & D_{2}\left(x_{1}\right)=\left\{0.1 / u_{1}, 0.6 / u_{2}, 0.8 / u_{3}\right\} & D_{3}\left(x_{1}\right)=\left\{0.3 / u_{1}, 0.2 / u_{2}, 0.7 / u_{3}\right\} \\
D_{1}\left(x_{2}\right)=\left\{0.2 / u_{1}, 0.6 / u_{2}, 0.1 / u_{3}\right\} & D_{2}\left(x_{2}\right)=\left\{0.4 / u_{1}, 0.9 / u_{2}, 0.2 / u_{3}\right\} & D_{3}\left(x_{2}\right)=\left\{0.1 / u_{1}, 0.5 / u_{2}, 0.6 / u_{3}\right\} \\
D_{1}\left(x_{3}\right)=\left\{0.3 / u_{1}, 0.7 / u_{2}, 0.2 / u_{3}\right\} & D_{2}\left(x_{3}\right)=\left\{0.2 / u_{1}, 0.3 / u_{2}, 0.7 / u_{3}\right\} & D_{3}\left(x_{3}\right)=\left\{0.6 / u_{1}, 0.1 / u_{2}, 0.1 / u_{3}\right\}
\end{array}
$$

First, there are given three matrix representations on fuzzy soft set: Let $U=\left\{u_{1}, u_{2}, u_{3}\right\}$ such that $u_{1}=$ house $1, u_{2}=$ house $2, u_{3}=$ house 3 and represented in Table 1 , Table 2 and Table 3, respectively. 


\begin{tabular}{|c|c|c|c|}
\hline \multirow{2}{*}{$\begin{array}{c}\text { House, } \\
i\end{array}$} & \multicolumn{3}{|c|}{ Criteria, $j$} \\
\cline { 2 - 4 } & Cheap & Modern & Large \\
\hline$u_{1}$ & 0.50 & 0.20 & 0.30 \\
$u_{2}$ & 0.20 & 0.60 & 0.70 \\
$u_{3}$ & 0.50 & 0.10 & 0.20 \\
\hline
\end{tabular}

\begin{tabular}{|c|c|c|c|}
\hline \multirow{2}{*}{$\begin{array}{c}\text { House, } \\
i\end{array}$} & \multicolumn{3}{|c|}{ Criteria,j } \\
\cline { 2 - 4 } & Cheap & Modern & Large \\
\hline$u_{1}$ & 0.30 & 0.10 & 0.60 \\
$u_{2}$ & 0.20 & 0.50 & 0.10 \\
$u_{3}$ & 0.70 & 0.60 & 0.10 \\
\hline
\end{tabular}

Table 3: Matrix Representation of Fuzzy Soft Set, $\left(F_{3}, S\right)$

\begin{tabular}{|c|c|c|c|}
\hline \multirow{2}{*}{$\begin{array}{c}\text { House, } \\
i\end{array}$} & \multicolumn{3}{|c|}{ Criteria, $j$} \\
\cline { 2 - 4 } & Cheap & Modern & Large \\
\hline$u_{1}$ & 0.10 & 0.40 & 0.20 \\
$u_{2}$ & 0.60 & 0.90 & 0.30 \\
$u_{3}$ & 0.80 & 0.20 & 7.00 \\
\hline
\end{tabular}

First step, establish the fuzzy decision matrix (FDM) by finding the average of fuzzy soft set as shown in Table 4. Then, normalize the fuzzy decision matrix (NFDM) by using relative performance of the generated design alternatives as in Table 5. Next, calculating the weighted normalized fuzzy decision matrix (WNFDM). Given weighted vector, $W=(0.34,0.37,0.29)$, then weighted normalized fuzzy decision matrix, $\mathrm{V}$ is obtained as Table 6.

Table 1: FDM

\begin{tabular}{|c|c|c|c|}
\hline House, & \multicolumn{3}{|c|}{ Criteria, $j$} \\
\cline { 2 - 4 }$i$ & Cheap & Modern & Large \\
\hline$u_{1}$ & 0.30 & 0.23 & 0.37 \\
$u_{2}$ & 0.33 & 0.67 & 0.37 \\
$u_{3}$ & 0.67 & 0.30 & 2.43 \\
\hline
\end{tabular}

Table 2: NFDM

\begin{tabular}{|c|c|c|c|}
\hline \multirow{2}{*}{$\begin{array}{c}\text { House, } \\
i\end{array}$} & \multicolumn{3}{|c|}{ Criteria, $j$} \\
\cline { 2 - 4 } & Cheap & Modern & Large \\
\hline$u_{1}$ & 0.3727 & 0.2990 & 0.1489 \\
$u_{2}$ & 0.4100 & 0.8709 & 0.1489 \\
$u_{3}$ & 0.8324 & 0.3900 & 0.9776 \\
\hline
\end{tabular}


Table 3: WNFDM

\begin{tabular}{|c|c|c|c|}
\hline \multirow{2}{*}{$\begin{array}{c}\text { House, } \\
i\end{array}$} & \multicolumn{3}{|c|}{ Criteria, $j$} \\
\cline { 2 - 4 } & Cheap & Modern & Large \\
\hline$u_{1}$ & 0.1267 & 0.1106 & 0.0432 \\
$u_{2}$ & 0.1394 & 0.3222 & 0.0432 \\
$u_{3}$ & 0.2830 & 0.1443 & 0.2835 \\
\hline
\end{tabular}

Then, next step is identified the Fuzzy Positive Ideal Solution (FPIS, $A^{+}$) and Negative Ideal Solution (FNIS, $A^{-}$) as shown in Table 9. Table 10 shows the ranking of alternatives based on TOPSIS of fuzzy soft sets with distinct ideal solutions and distance formulas.

Table 4: First application of different FPIS and FNIS result

\begin{tabular}{|c|c|c|c|}
\hline $\begin{array}{l}\text { Maximum and minimum value of } \\
\text { FPIS and FNIS }\end{array}$ & $\begin{array}{l}\text { FPIS, } A^{+}=(0.2830, \\
\text { FNIS, } A^{-}=(0.1267,\end{array}$ & $\begin{array}{l}0.3222, \\
0.1106,\end{array}$ & $\begin{array}{l}0.2835) \\
0.0432)\end{array}$ \\
\hline Universal set of FPIS and FNIS & $\begin{array}{l}\text { FPIS, } A^{+}=(1.0000, \\
\text { FNIS, } A^{-}=(0.0000,\end{array}$ & $\begin{array}{l}1.0000 \\
0.0000\end{array}$ & $\begin{array}{l}1.0000) \\
0.0000)\end{array}$ \\
\hline
\end{tabular}

Next, measure the relative closeness of each alternative to the ideal solution. The result of the relative closeness is based on three different distance formulas with two different FPIS and FNIS values. The relative closeness $C_{i}$ and ranking of alternatives shown as Table 10. 
INTERNATIONAL JOURNAL OF ACADEMIC RESEARCH ECONOMICS AND MANAGEMENT SCIENCES Vol. 10 , No. 2, 2020, E-ISSN: 2226-3624 ㄷ 2020 HRMARS

Table 10: Ranking of alternatives

\begin{tabular}{|c|c|c|c|c|c|c|c|c|}
\hline & \multicolumn{2}{|c|}{$\begin{array}{l}\text { Relative closeness } \\
\text { of Separation } \\
\text { distance by Hwang } \\
\text { \& Yoon (1981) }\end{array}$} & \multicolumn{2}{|c|}{$\begin{array}{l}\text { Relative closeness of } \\
\text { Euclidean distance } \\
\text { by Roshandel, Miri- } \\
\text { Nargesi, Hatami- } \\
\text { Shirkouhi (2013) }\end{array}$} & \multicolumn{2}{|c|}{$\begin{array}{l}\text { Relative closeness of } \\
\text { distance by Chu } \\
\text { (2002) }\end{array}$} & \multicolumn{2}{|c|}{$\begin{array}{l}\text { Article by } \\
\text { Eraslan and } \\
\text { Karaaslan, } \\
\text { (2015) }\end{array}$} \\
\hline \multirow{3}{*}{$\begin{array}{l}\text { Maximu } \\
m \text { and } \\
\text { minimum } \\
\text { values of } \\
\text { FPIS and } \\
\text { FNIS }\end{array}$} & $\begin{array}{c}\text { Ran } \\
k\end{array}$ & $C_{i}$ & $\begin{array}{c}\text { Ran } \\
k\end{array}$ & $C_{i}$ & $\begin{array}{c}\text { Ran } \\
k\end{array}$ & $C_{i}$ & \multirow{2}{*}{$\begin{array}{c}\text { Ran } \\
k\end{array}$} & \multirow{2}{*}{$\begin{array}{c}\text { Hous } \\
\mathrm{e}\end{array}$} \\
\hline & 3 & $\begin{array}{c}\text { House } 1= \\
0.0000\end{array}$ & 3 & $\begin{array}{c}\text { House } 1= \\
0.0000\end{array}$ & 3 & $\begin{array}{c}\text { House } 1= \\
0.0000\end{array}$ & & \\
\hline & $\begin{array}{l}2 \\
1\end{array}$ & $\begin{array}{c}\text { House } 2= \\
0.4309 \\
\text { House } 3= \\
0.6186\end{array}$ & 2 & $\begin{array}{c}\text { House } 2= \\
0.4309 \\
\text { House } 3= \\
0.6186\end{array}$ & 1 & $\begin{array}{c}\text { House } 2= \\
0.3688 \\
\text { House } 3= \\
0.7074\end{array}$ & \multirow{3}{*}{2} & $\begin{array}{l}\text { Hous } \\
\text { e } 1\end{array}$ \\
\hline \multirow{3}{*}{$\begin{array}{l}\text { Universal } \\
\text { set of } \\
\text { FPIS and } \\
\text { FNIS }\end{array}$} & $\begin{array}{c}\text { Ran } \\
k\end{array}$ & $C_{i}$ & $\begin{array}{c}\text { Ran } \\
k\end{array}$ & $C_{i}$ & $\begin{array}{c}\text { Ran } \\
k\end{array}$ & $C_{i}$ & & Hous \\
\hline & 3 & $\begin{array}{c}\text { House } 1= \\
0.0995\end{array}$ & 3 & $\begin{array}{c}\text { House } 1= \\
0.0995\end{array}$ & 3 & $\begin{array}{c}\text { House } 1= \\
0.0935\end{array}$ & & e 2 \\
\hline & $\begin{array}{l}2 \\
1\end{array}$ & $\begin{array}{c}\text { House } 2= \\
0.1956 \\
\text { House } 3= \\
0.2430\end{array}$ & 2 & $\begin{array}{c}\text { House } 2= \\
0.1956 \\
\text { House } 3= \\
0.2430\end{array}$ & 2 & $\begin{array}{c}\text { House } 2= \\
0.1683 \\
\text { House } 3= \\
0.2369\end{array}$ & 1 & $\begin{array}{l}\text { Hous } \\
\text { e } 3\end{array}$ \\
\hline
\end{tabular}

The second example taken from Das and Borgohain (2012).Suppose Mr.X is interested to buy a car from among the set of cars $U=\left\{c_{1}, c_{2}, c_{3}\right\}$ on the basis of the set $S=\left\{s_{1}\right.$ (costly), $s_{2}$ (comfort), $s_{3}$ (fuel efficiency), $s_{4}$ (maintenance) $\}$ of selection criteria called the parameters and suppose $\mathrm{Mr} . \mathrm{X}$ is interested to buy the car on his own preference weightage to the selection criteria.

$$
\begin{array}{lll}
F_{1}\left(s_{1}\right)=\left\{c_{1} / .8, c_{2} / .7, c_{3} / .4\right\} & F_{2}\left(s_{1}\right)=\left\{c_{1} / .5, c_{2} / .8, c_{3} / .4\right\} & F_{3}\left(s_{1}\right)=\left\{c_{1} / .2, c_{2} / .9, c_{3} / .4\right\} \\
F_{1}\left(s_{2}\right)=\left\{c_{1} / .4, c_{2} / .3, c_{3} / .5\right\} & F_{2}\left(s_{2}\right)=\left\{c_{1} / .7, c_{2} / .3, c_{3} / .4\right\} & F_{3}\left(s_{2}\right)=\left\{c_{1} / .5, c_{2} / .7, c_{3} / .4\right\} \\
F_{1}\left(s_{3}\right)=\left\{c_{1} / .6, c_{2} / .4, c_{3} / .4\right\} & F_{2}\left(s_{3}\right)=\left\{c_{1} / .9, c_{2} / .3, c_{3} / .6\right\} & F_{4}\left(s_{3}\right)=\left\{c_{1} / .4, c_{2} / .7, c_{3} / .8\right\} \\
F_{1}\left(s_{4}\right)=\left\{c_{1} / .3, c_{2} / .6, c_{3} / .7\right\} & F_{2}\left(s_{4}\right)=\left\{c_{1} / .4, c_{2} / .6, c_{3} / .8\right\} & F_{5}\left(s_{4}\right)=\left\{c_{1} / .6, c_{2} / .4, c_{3} / .8\right\}
\end{array}
$$


Table 11: Ranking of alternatives

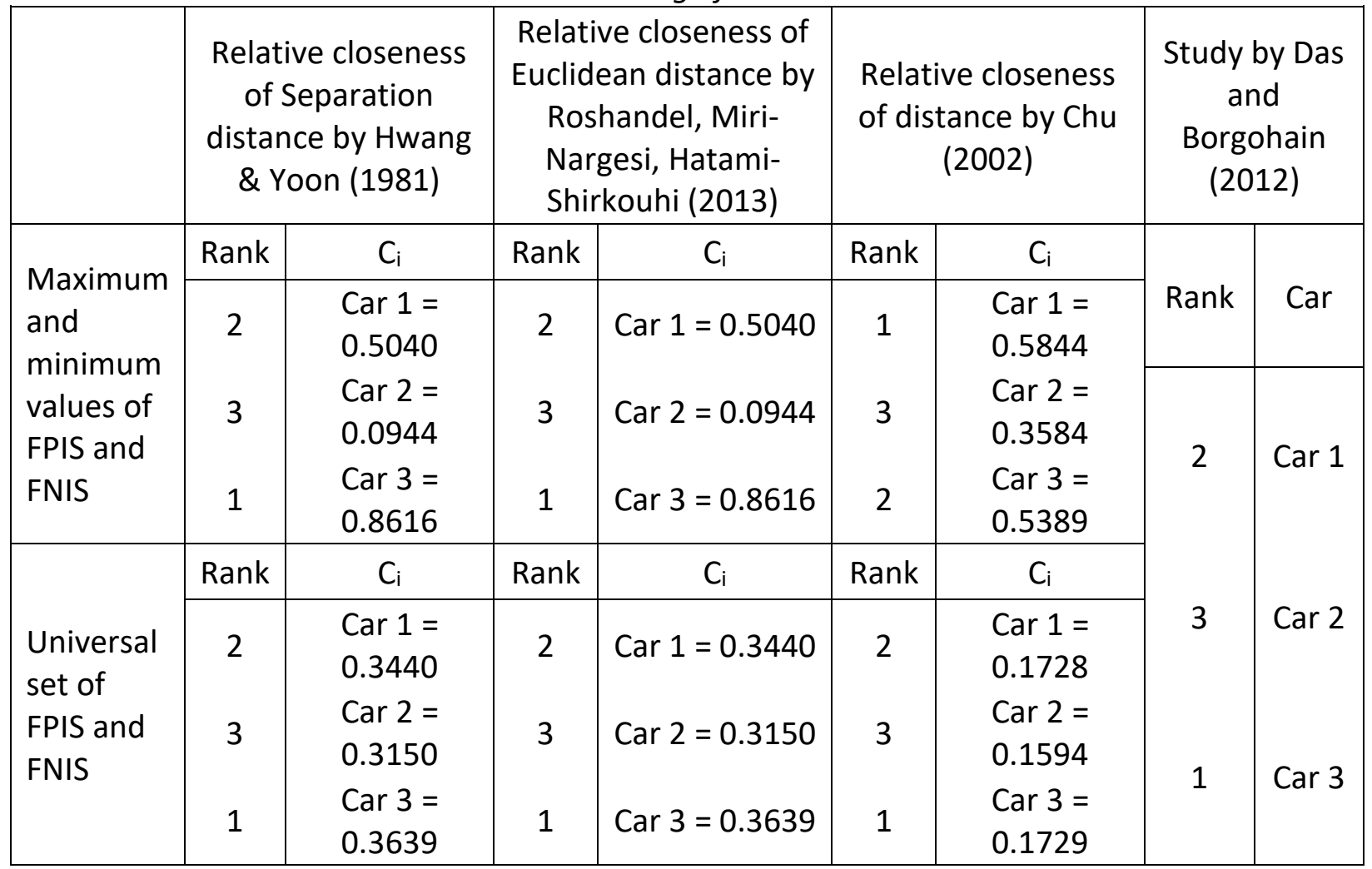

\section{Conclusion}

According to our proposed method's ranking, TOPSIS of fuzzy soft sets with distinct ideal solutions and distance formulas is consistent with Eraslan's (2015) and Das and Borgohain's (2012) rankings. In summary, the comparative study of FPIS and FNIS, as well as the distance formula in fuzzy soft set on TOPSIS, is important because it can aid future researchers in solving problems and making decisions.

The present study utilised two distinct FPIS and FNIS values: maximum and minimum values, as well as universal set values $(1,1,1)$. $(0,0,0)$. Additionally, three distinct distance formulas were used in this study: separation distance, Euclidean distance, and Chu's distance. Comparing these instances to those obtained through other approaches indicates that the ranking results are consistent regardless of which of these distance methods and distinct types of FPIS and FNIS values are employed. It is possible to suggest that these three distance formulas, as well as various types of FPIS and FNIS, could be utilised in conjunction with the MCDM technique.

For future research, it is recommended to conduct additional comparisons of FPIS and FNIS and to investigate additional distance formulas, as there are numerous distance formulas in fuzzy TOPSIS proposed by previous researchers.

\section{References}

Alcantud, J. C. R., De Andrés Calle, R., \& Torrecillas, M. J. M. (2016). Hesitant Fuzzy Worth: An innovative ranking methodology for hesitant fuzzy subsets. Applied Soft Computing Journal, 38, 232-243. https://doi.org/10.1016/j.asoc.2015.09.035 
Alidoosti, A., Yazdani, M., Fouladgar, M. M., \& Basiri, M. H. (2012). Risk assessment of critical asset using fuzzy inference system. Risk Management, 14(1), 77-91.

Alsager, K. M., Alshehri, N. O., \& Akram, M. (2018). A decision-making approach based on a multi Q-hesitant fuzzy soft multi-granulation rough model. Symmetry, 10(12). https://doi.org/10.3390/sym 10120711

Bashir, M., \& Salleh, A. R. (2012). Fuzzy parameterized soft expert set. Abstract and Applied Analysis, 2012, 1-15. https://doi.org/10.1155/2012/258361

Beg, I., \& Rashid, T. (2016). Ideal solutions for hesitant fuzzy soft sets. Journal of Intelligent and Fuzzy Systems, 30(1), 143-150. https://doi.org/10.3233/IFS-151740

Chu, T. C. (2002). Selecting plant location via a fuzzy TOPSIS approach. The International Journal of Advanced Manufacturing Technology, 20(11), 859-864.

Das, P. K., \& Borgohain, R. (2012). An application of generalized interval-valued intuitionistic fuzzy soft sets in a decision making problem. International Journal of Computer Applications 38(12): 33.37.

Eraslan, S. (2015). A decision making method via TOPSIS on soft sets. Journal of New results in Science, 4(8).

Hwang, C.-L., \& Yoon, K. (1981). Multiple Attribute Decision Making - Methods and Applications. https://doi.org/10.1007/978-3-642-45511-7

Khan, M. J., Kumam, P., Ashraf, S., \& Kumam, W. (2019). Generalized picture fuzzy soft sets and their application in decision support systems. Symmetry, 11(3), 1-27. https://doi.org/10.3390/sym11030415

Li, C., Li, D., \& Jin, J. (2019). Generalized Hesitant Fuzzy Soft Sets and Its Application to Decision Making. International Journal of Pattern Recognition and Artificial Intelligence, 33(12), 130. https://doi.org/10.1142/S0218001419500198

Maji, P. K., Biswas, R., \& Roy, A. R. (2001). Fuzzy soft sets. Journal of Fuzzy Mathematics, 9(3), 589-602.

Maji, P., Biswas, R., \& Roy, A. (2003). Soft set theory. Computers \& Mathematics with Applications, 45(4-5), 555-562.

Majumdar, P., \& Samanta, S. K. (2010). Generalised fuzzy soft sets. Computers \& Mathematics with Applications, 59(4), 1425-1432.

Marković, Z. (2016). Modification of TOPSIS method for solving of multicriteria tasks. Yugoslav Journal of Operations Research, 20(1).

Mokhtia, M., Eftekhari, M., \& Saberi-Movahed, F. (2020). Feature selection based on regularization of sparsity based regression models by hesitant fuzzy correlation. Applied Soft Computing Journal, 91, 106255. https://doi.org/10.1016/j.asoc.2020.106255

Molodtsov, D. (1999). Soft set theory-First results. Computers \& Mathematics with Applications, 37(4), 19-31.

Roshandel, J., Miri-Nargesi, S. S., \& Hatami-Shirkouhi, L. (2013). Evaluating and selecting the supplier in detergent production industry using hierarchical fuzzy TOPSIS. Applied Mathematical Modelling, 37(24), 10170-10181.

Roy, A. R., \& Maji, P. (2007). A fuzzy soft set theoretic approach to decision making problems. Journal of Computational and Applied Mathematics, 203(2), 412-418.

Sun, G., Guan, X., Yi, X., \& Zhou, Z. (2018). An innovative TOPSIS approach based on hesitant fuzzy correlation coefficient and its applications. Applied Soft Computing Journal, 68, 249-267. 
INTERNATIONAL JOURNAL OF ACADEMIC RESEARCH ECONOMICS AND MANAGEMENT SCIENCES Vol. 10 , No. 2, 2020, E-ISSN: 2226-3624 ㄷ 2020 HRMARS

https://doi.org/10.1016/j.asoc.2018.04.004

Wang, J. Q., Li, X. E., \& Chen, X. H. (2015). Hesitant fuzzy soft sets with application in multicriteria group decision making problems. Scientific World Journal, 2015. https://doi.org/10.1155/2015/806983

Wang, L., \& Qin, K. (2019). Incomplete fuzzy soft sets and their application to decision-making. Symmetry, 11(4). https://doi.org/10.3390/sym11040535. 